DOI https://doi.org/10.18551/rjoas.2020-12.20

\title{
CONTRIBUTION OF SPINDLE-LESS ROTARY LATHE AND ITS EFFECT ON THE YIELD OF PEELED VENEERS AT PT. RIMBA RAYA LESTARI, KUTAI KARTANEGARA, EAST KALIMANTAN OF INDONESIA
}

\author{
Syafii ${ }^{\star}$, Bandi Supraptono, Edy Budiarso, Agus Sulistyobudi \\ Samarinda State Agricultural Polytechnic, Indonesia \\ *E-mail: aliefsyafii.10@gmail.com
}

\begin{abstract}
Rotary veneer peeling lathes with large spindles are widely used in veneer and plywood manufacturing plants in Indonesia. On average, half of the raw material logs become waste and $25 \%$ is contributed by the rotary lathe. Meanwhile, on the other hand, the world's demand for plywood products will never disappear, even will continue to rise. This is because plywood is one of the most environmentally friendly building material products deriving from renewable natural resources. With the regrowth of the plywood industry as in its former heyday, the demand for log raw materials will also increase in line with the potential for loss of logs as waste. In this regard, there must be fundamental changes in this industry, including the change in production machines from large rotary spindles to spindle-less. The purpose is to analyze its contribution to increasing the peeled veneer yield or volume. Furthermore, it aims to find out the volume of by-products, log-core, and spur-knife waste. The difference in results between the two types of lathes (spindle and spindle-less rotary lathes) was also tested. This study used a $3 \times 2 \times 5$ factorial experimental design, with three factors or fixed variables: Quality, Diameter Range of Raw Material Logs, and Types of Rotary Lathe. Based on the analysis of the results of the calculations, in general, the spindleless rotary lathe provided a yield of more than $60 \%$ of the raw material logs peeled off into veneers, in the form of continuous/endless veneers and poly piece core/odd veneers, in all quality and diameter classes, and the rest was waste in the form of round-up veneer and logcore by $15 \%$ with an average diameter of $23 \mathrm{~cm}$. If the peeling was continued to a diameter of $7 \mathrm{~cm}$, this would increase the veneer yield by more than $10 \%$. The statistical analysis showed that only the factor of different types of rotary lathe had a nearly significant effect on the yield of the peeled veneer. The interaction of the three factors tested also had a very significant effect on the yield of the peeled veneer.
\end{abstract}

\section{KEY WORDS}

Spindle-less rotary lathe, veneer, yield.

The world's demand for veneer products and/ or plywood will continuously increase over time because plywood is one of the most environmentally friendly building material products deriving from renewable natural resources. Therefore, the plywood industry must be encouraged to make positive changes such as shifting the use of raw materials from forest wood to plant wood, especially Sengon (Parasentiathes falcataria) wood, shifting large-scale industry to small-medium-scale industry, shifting the production machines from large rotary spindles to spindle-less. The latter is the most important because it promises a higher and more qualified yield of peeled veneers.

This study aims to provide an overview of the yield resulted from the spindle-less peeling machine, especially in the form of continuous veneers and poly piece core veneers. According to Kollmann et al. (1975), the wood commonly used as the raw material for veneers or plywood in Asia is mainly from the Dipterocarpaceae family. Although the types of Dipterocarpaceae exist in mixed forests, they account for more than half of the potential of stands in it and are only distinguished by strength, straightness and knot-freeness in the trunk, such as Red Meranti, White Meranti, and Mersawa. The other types are Jelutung and Ramin. Veneer manufacture requires logs with straight fibers. Deviations from this provision are permitted to the extent that they are considered economical and meeting the quality 
requirement. However, the logs used as raw materials for veneers are expensive. Besides, the logs must be round or cylindrical. Dumanauw (1996) requires that the logs for veneer manufacture must be large in diameter, round, defect-free or moderate-weighted, for example, Red Meranti, White Meranti, Nyatoh, Ramin, Agathis, Benuang. Haygeen and Bowyer (1993) asserted that the quality of logs is determined by the absence of knots or surface defects, straight and cylindrical shapes, and freeness of defective ends. "Bontos" defects or rots are also a serious problem of logs for veneers. The quality class is commonly determined based on straightness, freeness of bontos rots (softness in the middle) and freeness of knots or other defects. Furthermore, it is said that the quality of logs entering the manufacturing plant is important for two things, namely controlling the quality and yield of veneers and reducing the number of logs proven to be defective after being installed in a peeling machine. Defective logs or sawn-logs can reduce the production speed of peeling machines (Haygeen and Bowyer, 1993). Fruehwald (1986) explained in more detail that the logs to be converted into veneer sheets must be available in large quantities, free from defects (such as knots, pinholes, broken ends or surfaces) and have a density between 0,35 $-0.8 \mathrm{~g} / \mathrm{cm}^{3}$, a diameter $>40 \mathrm{~cm}$, straight and cylindrical shapes, straight fibers, high mechanical properties, decorative texture, light color and low prices.

According to Wood and Linn (1950), there are two different ways to produce veneer. First, veneers are peeled from logs on a rotary-cutter machine, which is the most widely used way. Second, veneers are peeled from log-blocks that have been made to a certain size. The process of manufacturing veneers from logs applies a rotary-cutting method on a rotary lathe. Meanwhile, the production of veneers from log-blocks applies a slicing method, including horizontal slicing and vertical slicing. The sawing method is used to produce veneers from log-blocks for a specific purpose, such as thick veneers. According to Kollmann et al (1975), most veneers are manufactured using rotary-peeling, which is the basis of the modern plywood industry. Rotary-peeling aims to produce endless veneers (continuous long veneers). Although it is not completely perfect, veneers manufactured in this way are smooth on both surfaces. Britannica (2002) explained that more than $90 \%$ of veneers are peeled products. However, those from figurative logs for furniture and other decorative uses are manufactured by a slicing method while sawn veneers are rarely manufactured because it produces a lot of waste.

\section{METHODS OF RESEARCH}

This research was conducted at plywood (ply mill) manufacturing plant, in Loa Kulu Village, Kutain Kertanegara Regency, East Kalimantan, namely PT Rimba Raya Lestari (PT $\mathrm{RRL})$. In this case, the research object was only logs of Meranti Merah species.

Veneer cutting/ peeling procedure. After the logs with a size of $10-17 \mathrm{~m}$ were cut into certain sizes (3', 4, 6' and 8'), the log-blocks were measured again for their length and diameter to calculate the input volume of raw materials. Then, the blocks were taken to the log debarking machine to remove all the skin and other foreign objects attached to the block surfaces. From the log debarking machine still with the same roll conveyor, the blocks moved towards the log cleaning device for block cleaning by spraying high-pressure water to clean the leftover dirt attached to the blocks. In this case, there was no pretreatment of log-block steaming and boiling.

Log-block peeling. The blocks were placed on the conveyor chain deck to wait for the turn to determine the log-block centering. Moreover, the blocks were taken to the rotary lathe. The hoist equipped with clamps performs this task until the block was gripped by the two spindles. As the peeling process progressed, the spindles were slowly pulled so that the log remaining rotating against the rodent blade was only clamped by the knife-holder and nozzle wheels. The results in the form of long veneers (continuous veneers) were rolled up and then temporarily placed on the reeling-unreeling veneer decks. At the same time, oddveneer (poly piece core) and edge-cut veneer (spur-knife waste) also resulted at the beginning and end of the peeling. This peeling process ended by leaving pith (log-core).

Handling of veneers and other peeled products. The thickness of all peeled veneers, 
both continuous veneers, poly piece core and spur-knife waste, were measured and marked as $t(\mathrm{~mm})$. The radius $(r, \mathrm{~cm})$ and length $(I \mathrm{~cm})$ were measured specifically for veneer rolls on the reeling-unreeling decks. After the diameter of the bobbin roller was known, the veneer volume was then calculated. The calculated volume was marked as $\left(V \mathrm{~cm}^{3}\right)$. The pith (logcore) was measured for length (I) and diameter (d) to calculate the volume, and then directed to the stacking place through a channel under the rotary lathe equipped with a v-belt conveyor.

Measurement and testing. Measurement of the diameter, log-block volume and veneer volume on rolls were calculated according to the formulas below (Syafii, 2019). The formula for measuring log-block and pith diameter (1):

$$
D=\frac{1 / 2\left[\left(d_{1}+d\right)^{+}(d+d)\right]}{2}(\mathrm{~cm})
$$

Where: $D=$ log-block or pith diameter (in $\mathrm{cm}$ ); $d 1, d 2, d 3$ and $d 4=$ the diameter resulted from four-times measurements $(\mathrm{cm})$.

The formula for measuring log-block and pith volume:

$$
V=\left(1 / 4 \pi D^{2}\right) \times I\left(\mathrm{~m}^{3}\right)
$$

Where: $V=$ volume (in $\left.\mathrm{m}^{3}\right) ; l=$ log-block or pith length $(\mathrm{m}) ; \pi=3.14$.

Veneer Volume. Veneer gross volume in bobbin rollers on the reeling-unreeling machine was calculated according to the following formula:

$$
\mathrm{V}=1 / 4 \pi\left(B_{\mathrm{v}}{ }^{2}-B_{\mathrm{b}}{ }^{2}\right) \times /\left(\mathrm{m}^{3}\right)
$$

Where: $B v=$ Veneer roll diameter $(m) ; B b=$ Bobbin diameter $(m)$.

Treatments and experimental design. To see the effect of treatments and the interaction of treatments and the output of the peeling on the rotary lathe, the data and calculation results were then tabulated and analyzed based on a $3 \times 2 \times 5$ factorial experimental design, consisting of 1) Factor A (log-block quality) covering 3 levels, namely Class A $\left(a_{1}\right)$, Class $B\left(a_{2}\right)$ and Class $\left.C\left(a_{3}\right) ; 2\right)$ Factor $B$ (diameter) covering 5 levels, consisting of $50-54 \mathrm{~cm}\left(\mathrm{c}_{1}\right), 55-59 \mathrm{~cm}\left(\mathrm{c}_{2}\right), 60-64 \mathrm{~cm}\left(\mathrm{c}_{3}\right), 65-69 \mathrm{~cm}\left(\mathrm{c}_{4}\right)$, and $70-44$ $\mathrm{cm}\left(c_{5}\right) .3$ ) Factor $C$ (types of rotary lathes) consisting of 2 levels, namely $b_{1}$ and $b_{2}$.

\section{RESULTS AND DISCUSSION}

The observation results include the diameter, length and volume of the log-blocks fed to the two types of rotary lathe.

Table 1 - Average Dimension Measurement Results of Log-Blocks Fed to the Rotary Lathes

\begin{tabular}{c|lll|lll}
\hline Factors & \multicolumn{3}{l}{ Spindle-less Rotary Lathe } & & \multicolumn{3}{l}{ Spindle Rotary Lathe } \\
\hline Quality & Diameter $(\mathrm{cm})$ & Length $(\mathrm{cm})$ & Volume $\left(\mathrm{m}^{3}\right)$ & Diameter $(\mathrm{cm})$ & Length $(\mathrm{cm})$ & Volume $\left(\mathrm{m}^{3}\right)$ \\
\hline Minimum & 45.6 & 258.0 & 0.4254 & 63.4 & 106 & 0.598 \\
A Maximum & 82.0 & 261.8 & 13.750 & 73.63 & 199 & 0.768 \\
Average & 63.13 & 260.31 & 0.8300 & 80 & 203.5 & 0.860 \\
\hline Minimum & 52.0 & 257.7 & 0.5470 & 60 & 198 & 19.579 \\
B Maximum & 74.7 & 261.3 & 11.389 & 78.5 & 205 & 10.762 \\
Average & 62.14 & 259.75 & 0.8000 & 71.92 & 106 & 0.820 \\
\hline Minimum & 51.0 & 259.0 & 0.4254 & 63 & 0.318 \\
C Maximum & 72.0 & 260.0 & 13.750 & 81.0 & 199 & 133.27 \\
Average & 61 & 259.51 & 0.8300 & 71.50 & & 1.539 \\
\hline
\end{tabular}

The average diameters of log-blocks fed to the spindle-less rotary lathe were $63.13 \mathrm{~cm}$ (Quality Class A), $62.14 \mathrm{~cm}$ (Quality Class B) and $61.00 \mathrm{~cm}$ (Quality Class C). Meanwhile, those fed to the spindle rotary lathe (conventional machine) had average diameters of 80.00 
cm (Quality Class A), $71.92 \mathrm{~cm}$ (Quality Class B), and $71.50 \mathrm{~cm}$ (Quality Class C) respectively. Table 1 above presents the value of each volume calculation.

The complete results of the log-block conversion to veneers using the spindle-less rotary lathe machine are presented in Table 2. The value for each row is the average of 3 replication. Each log-block peeling into a veneer sheet was ensured to be followed by 3 results of other materials in the form of waste, except log-cores. The peeled product obtaining the largest volume was continuous/ endless veneer, reaching $58.66 \%, 50.01 \%$ and 49.27 for Log-Block Quality Class A, B, and C respectively. Furthermore, poly piece core (odd veneer) obtained volumes of $25.66 \%, 19.80 \%$, and $18.20 \%$ for Log-Block Quality Class $\mathrm{A}, \mathrm{B}$, and $\mathrm{C}$ respectively. Meanwhile, the volumes of log-core for the three quality classes were $12.13 \%, 15.06 \%$, and $11.84 \%$ respectively. The edges cut by the spur-knife were ensured to be waste, each of which amounted to $0.95 \%, 0.92 \%$, and $0.93 \%$ respectively for Log-Block Quality Class A, B, and C. Muladi in Schulte and Schone (1996) stated that $72.84 \%$ veneers resulted from the logs while the remaining $27.16 \%$ was waste.

The yield of the face and back veneers (continuous veneers) varied from $51.88 \%$ (Yellow Meranti) to 74.55\% (Red Meranti). Syafii (2001) reported that the percentages of peeled yields reached $58 \%$ for endless veneers (complete veneers), $27 \%$ of odd veneers (poly piece core), $10 \%$ of piths (log-core), and $5 \%$ of spur-knife waste.

\section{Table 2 - Peeled Yields of Log-Blocks in Different Diameter and Quality Classes (in $\mathrm{m}^{3}$ ) using Spindle-less Rotary Lathe}

\begin{tabular}{|c|c|c|c|c|c|c|c|c|c|c|c|c|c|c|c|}
\hline \multicolumn{6}{|c|}{ Quality Class A } & \multicolumn{5}{|c|}{ Quality Class B } & \multicolumn{5}{|c|}{ Quality Class C } \\
\hline $\begin{array}{l}\text { Range of } \\
\text { Log } \\
\text { Diameter } \\
(\mathrm{cm})\end{array}$ & $\begin{array}{l}\text { Average } \\
\text { Log } \\
\text { Diameter } \\
(\mathrm{cm})\end{array}$ & $\begin{array}{c}\text { Vol. of } \\
\text { Continuous } \\
\text { Veneer }\left(\mathrm{m}^{3}\right)\end{array}$ & $\begin{array}{c}\text { Vol. of } \\
\text { poly } \\
\text { piece } \\
\text { core } \\
\left(\mathrm{m}^{3}\right)\end{array}$ & $\begin{array}{c}\text { Vol. of } \\
\text { log- } \\
\text { core } \\
\left(\mathrm{m}^{3}\right)\end{array}$ & $\begin{array}{c}\text { Vol. of } \\
\text { spur- } \\
\text { knife } \\
\text { waste } \\
\left(\mathrm{m}^{3}\right)\end{array}$ & $\begin{array}{l}\text { Average } \\
\text { Log } \\
\text { Diameter } \\
\text { (cm) }\end{array}$ & $\begin{array}{c}\text { Vol. of } \\
\text { Continuous } \\
\text { Veneer }\left(\mathrm{m}^{3}\right)\end{array}$ & $\begin{array}{c}\text { Vol. of } \\
\text { poly } \\
\text { piece } \\
\text { core } \\
\left(\mathrm{m}^{3}\right)\end{array}$ & $\begin{array}{c}\text { Vol. of } \\
\text { log- } \\
\text { core } \\
\left(\mathrm{m}^{3}\right)\end{array}$ & $\begin{array}{c}\text { Vol. of } \\
\text { spur- } \\
\text { knife } \\
\text { waste } \\
\left(\mathrm{m}^{3}\right)\end{array}$ & $\begin{array}{l}\text { Average } \\
\text { Log } \\
\text { Diameter } \\
(\mathrm{cm})\end{array}$ & $\begin{array}{c}\text { Vol. of } \\
\text { Continuous } \\
\text { Veneer }\left(\mathrm{m}^{3}\right)\end{array}$ & $\begin{array}{c}\text { Vol. of } \\
\text { poly } \\
\text { piece } \\
\text { core } \\
\left(\mathrm{m}^{3}\right)\end{array}$ & $\begin{array}{c}\text { Vol. of } \\
\text { log- } \\
\text { core } \\
\left(\mathrm{m}^{3}\right)\end{array}$ & $\begin{array}{c}\text { Vol. of } \\
\text { spur- } \\
\text { knife } \\
\text { waste } \\
\left(\mathrm{m}^{3}\right)\end{array}$ \\
\hline $50-54$ & 49.97 & 0.229 & 0,208 & 0.142 & 0.004 & 52.67 & 0.194 & 0.142 & 0.050 & 0.006 & 52.67 & 0.111 & 0.150 & 0.046 & 0.006 \\
\hline $55-59$ & 57.83 & 0.297 & 0,295 & 0.142 & 0.005 & 56.33 & 0.189 & 0.142 & 0.103 & 0.005 & 56.56 & 0.088 & 0.129 & 0.069 & 0.007 \\
\hline $60-64$ & 62.57 & 0.327 & 0,256 & 0.208 & 0.005 & 61.67 & 0.362 & 0.142 & 0.101 & 0.007 & 61.00 & 0.135 & 0.140 & \begin{tabular}{|l|}
0.121 \\
\end{tabular} & 0.006 \\
\hline $65-69$ & 67.60 & 0.269 & 0,251 & 0.295 & 0.009 & 67.00 & 0.375 & 0.215 & 0.114 & 0.008 & 71.00 & 0.186 & 0.105 & 0.121 & 0.009 \\
\hline $70-74$ & 77.67 & 0.599 & 0,297 & 0.256 & 0.018 & 73.03 & 0.602 & 0.108 & 0.115 & 0.011 & 0.00 & 0.000 & 0.000 & 0.000 & 0.000 \\
\hline AVE & 63.13 & 0.344 & 0,260 & 0.209 & 0.008 & 62.14 & 0.344 & 0.150 & 0.097 & 0.008 & 61.00 & 0.132 & 0.129 & 0.090 & 0.007 \\
\hline
\end{tabular}

Spindleless rotary lathes have a great potential to replace the conventional one (rotary lathes with large-sized spindles). Even though some plywood industries are trying to innovate to have a diameter of not more than $12 \%$, it is often unsuccessful because of the large pressure of the dogging spindle at the time of peeling while the log-core diameter progressively decreases. This often makes the pith to vibrate and break while the peeling is in the progress. Replacing this rotary type with the spindle-less type is a revolutionary step to restore the glory of the industry and production of veneers and plywood from the past two decades. Plywood is the prima donna wood-based material products - panel products made from forest products in the form of wood. The peeled yield of the spindle-less rotary lathe above is quite encouraging although sometimes it is still inferior if compared to the conventional one when the peeled products are log-blocks with a large diameter, especially above $80 \mathrm{~cm}$. In this case, the old type of rotary lathe is still reliable.

Table 3 - Peeled Yields of Red Meranti Log-Blocks in Different Diameter and Quality Classes (in $\mathrm{m}^{3}$ ) using Spindle-less Rotary Lathe

\begin{tabular}{|c|c|c|c|c|c|c|c|c|c|c|c|c|c|c|c|}
\hline \multicolumn{6}{|c|}{ Quality Class A } & \multicolumn{5}{|c|}{ Quality Class B } & \multicolumn{5}{|c|}{ Quality Class C } \\
\hline $\begin{array}{l}\text { Range of } \\
\text { Log } \\
\text { Diameter } \\
(\mathrm{cm})\end{array}$ & $\begin{array}{l}\text { Average } \\
\text { Log } \\
\text { Diameter } \\
\text { (cm) }\end{array}$ & $\begin{array}{c}\text { Vol. of } \\
\text { Continuous } \\
\text { Veneer }\left(\mathrm{m}^{3}\right)\end{array}$ & $\begin{array}{c}\text { Vol. of } \\
\text { poly } \\
\text { piece } \\
\text { core } \\
\left(\mathrm{m}^{3}\right)\end{array}$ & $\begin{array}{l}\text { Vol. of } \\
\text { log- } \\
\text { core } \\
\left(\mathrm{m}^{3}\right)\end{array}$ & $\begin{array}{c}\text { Vol. of } \\
\text { spur- } \\
\text { knife } \\
\text { waste } \\
\left(\mathrm{m}^{3}\right)\end{array}$ & $\begin{array}{l}\text { Average } \\
\text { Log } \\
\text { Diameter } \\
(\mathrm{cm})\end{array}$ & $\begin{array}{c}\text { Vol. of } \\
\text { Continuous } \\
\text { Veneer }\left(\mathrm{m}^{3}\right)\end{array}$ & $\begin{array}{c}\text { Vol. of } \\
\text { poly } \\
\text { piece } \\
\text { core } \\
\left(\mathrm{m}^{3}\right)\end{array}$ & $\begin{array}{c}\text { Vol. of } \\
\text { log- } \\
\text { core } \\
\left(\mathrm{m}^{3}\right)\end{array}$ & $\begin{array}{c}\text { Vol. of } \\
\text { spur- } \\
\text { knife } \\
\text { waste } \\
\left(\mathrm{m}^{3}\right)\end{array}$ & $\begin{array}{l}\text { Average } \\
\text { Log } \\
\text { Diameter } \\
(\mathrm{cm})\end{array}$ & $\begin{array}{c}\text { Vol. of } \\
\text { Continuous } \\
\text { Veneer }\left(\mathrm{m}^{3}\right)\end{array}$ & $\begin{array}{c}\text { Vol. of } \\
\text { poly } \\
\text { piece } \\
\text { core } \\
\left(\mathrm{m}^{3}\right)\end{array}$ & $\begin{array}{l}\text { Vol. of } \\
\text { log- } \\
\text { core } \\
\left(\mathrm{m}^{3}\right)\end{array}$ & $\begin{array}{l}\text { Vol. of } \\
\text { spur- } \\
\text { knife } \\
\text { waste } \\
\left(\mathrm{m}^{3}\right)\end{array}$ \\
\hline & & 308 & 0.198 & 0.067 & 0.009 & & 0.3 & 0.104 & 30 & 0.038 & & 0.3 & 0.113 & 0.033 & 0.011 \\
\hline & 6 & 0.377 & 0.163 & 0.059 & 0.002 & 0 & 0.491 & 0.164 & 0.074 & 0.009 & 67 & 0.408 & 0.097 & 0.050 & 0.009 \\
\hline & 76.333 & 0.643 & 0.108 & 0.089 & 0.016 & 74.667 & 0.401 & 0.305 & 0.128 & 0.008 & 71.667 & 0.287 & 0.097 & 0.018 & 0.009 \\
\hline 79 & 80.067 & 0.579 & 0.234 & 0.088 & 0.007 & 76.833 & 0.658 & 0.195 & 0.073 & 0.029 & 76. & 0.319 & 0.165 & 0.024 & 0.014 \\
\hline-84 & 81.766 & 0.599 & 0.245 & 0.091 & 0.01 & 81.833 & 0.721 & 0.251 & 0.089 & 0.028 & 80.500 & 0.548 & 0.190 & 0.057 & 0.042 \\
\hline Rata- rata & 73.63 & 0.484 & 0.208 & 0.078 & 0.01 & 71.92 & 0.529 & 0.204 & 0.089 & 0.023 & 71.5 & 0.358 & 0.131 & 0.034 & 0.016 \\
\hline
\end{tabular}


Table 3 above presents the complete results of log-block conversion to veneers using the conventional rotary lathe (with spindles). In the observation of this section, there were almost no log-blocks with small diameters. Most of the blocks were over $70 \mathrm{~cm}$ in diameter instead. The physical display also showed a good log quality. The yields obtained were extraordinarily good, quite high and beyond expectation, covering continuous veneers of $55.54 \%$, PPC veneers of $24.53 \%$, log-cores of $9.18 \%$, and spur-knife waste of $1.08 \%$ for Log-Block Quality Class A. As for Log-Block Quality Class B, the yields showed continuous veneers of $61.48 \%$, PPC veneers of $24.48 \%$, log-cores of $11.08 \%$, spur-knife waste of $2.90 \%$. Meanwhile, the yields obtained in Log-Block Quality C consisted of continuous veneers of $44.86 \% \%$, PPC veneers of $26.72 \%$, log-cores of $6.03 \%$, spur-knife waste of $3.26 \%$. Haygeen and Bowyer (1993) identified that data obtained from a sawn-log peeling result showed $43 \%$ complete peeled veneers (continuous or endless veneers) plus $1 \%$ lowquality veneers. The loss due to rounding, veneer shrinkage, and veneer tears amounted to $43 \%, 3 \%$, and $2 \%$ respectively. Moreover, the log end and edge cutting loss was $26 \%$ and the log-core was $19 \%$. Baldwin (1981) found that the volume of green veneer ranged from $45.89 \%$ to $55.05 \%$.

Table ANOVA below (Table 4), compiled based on Gaspers (1994) and Steel and Torrie (1993), suggests that treatments, in all classes of quality, diameter and peeling machine type, turn out to not affect the volume of continuous veneers, both at the level of $\alpha=0.01$ and $\alpha=0.05$. The $F_{\text {table }}$ value is much greater than the $F_{\text {count }}$ value at the $5 \%$ test level. The results of this analysis of variance indicate that the classes of block quality, diameter and rotary lathe type used do not significantly affect the yield of continuous veneers. That is, there are other factors outside of the three treatments influencing the increase or decrease in the number of continuous veneers. One of the possible factors is the technical ability of the rotary lathe operator in the peeling process or the thickness of the peeled veneer. However, it appears that the interaction of the three treatments had a very significant effect on the volume of continuous veneers. The factor of the use of different rotary lathe types in peeling the blocks into veneer sheets was also limited to almost having a significant effect, indicated from the $F_{\text {count }}$ value almost approaching the $T_{\text {table }}$ at the level of $\alpha=0,05$.

Table 4 - Analysis of Variance (ANOVA) Data of Continuous Veneer Volumes in the $3 \times 2 \times 5$ Factorial Experimental Design

\begin{tabular}{|c|c|c|c|c|c|c|}
\hline \multirow{2}{*}{ Source } & \multirow{2}{*}{$\mathrm{db}$} & \multirow{2}{*}{ JK } & \multirow{2}{*}{$\mathrm{KT}$} & \multirow{2}{*}{ F-count } & \multicolumn{2}{|c|}{ F-table } \\
\hline & & & & & $5 \%$ & $1 \%$ \\
\hline Treatments & 29 & 1.67979 & 0.16798 & 5.02034 & & \\
\hline$A=$ Quality & 2 & 0.07832 & 0.03916 & $1.17036^{\mathrm{ns}}$ & 3.12 & 4.92 \\
\hline $\mathrm{B}=$ Diameter & 4 & 0.07132 & 0.01783 & $0.53285^{\mathrm{ns}}$ & 2.35 & 3.29 \\
\hline C = RL Type & 1 & 0.09744 & 0.09744 & $2.91225^{\mathrm{ns}}$ & 3.92 & 7.01 \\
\hline$A B$ & 8 & 0.03175 & 0.00397 & $0.11863^{\mathrm{ns}}$ & 1.97 & 2.589 \\
\hline$A C$ & 2 & 0.00726 & 0.00363 & $0.10855^{\mathrm{ns}}$ & 3.12 & 4.92 \\
\hline $\mathrm{BC}$ & 4 & 0.00263 & 0.00066 & $0.01965^{\mathrm{ns}}$ & 2.35 & 3.29 \\
\hline$A B C$ & 8 & 1.39106 & 0.17388 & $5.19678^{\star *}$ & 1.97 & 2.589 \\
\hline Error & 58 & 1.94066 & 0.03346 & & & \\
\hline Total & 116 & 3.62046 & & & & \\
\hline
\end{tabular}

Note: $n s=$ not significant different at $\alpha=0.05 ;{ }^{* *}=$ very significant different at $\alpha=0.01$.

Almost the same situation is shown in the results of the analysis of variance of the poly piece core veneer data. However, the general description of the $F_{\text {count }}$ value resulted (Table 5 ) from each treatment still indicates a very small value, far from the $F_{\text {table }}$ value at the level of $\alpha=0.01$, even at the level of $\alpha=0.05$. In other words, individual treatments did not affect the yield of PPC veneers. Generally, the raw material blocks fed to the peeling machine are relatively cylindrical because they have been sorted in such a way from the start, except in certain cases due to a scarcity of raw material logs. Meanwhile, noncylindrical log-blocks contribute significantly to the acquisition of poly piece core veneers when peeling. A very significant effect was shown by the interaction of the three treatments, both at the level of $\alpha=$ 0.05 and $\alpha=0.01$, influencing the volume of the PPC veneers resulted. The different peeling machine types seemed to not affect the volume of PPC veneers as well. 
Table 5 - Analysis of Variance (ANOVA) Data of PPC Veneer Volumes in the $3 \times 2 \times 5$ Factorial Experimental Design

\begin{tabular}{|c|c|c|c|c|c|c|}
\hline Source & $\mathrm{db}$ & JK & KT & $\mathrm{F}_{\text {count }}$ & $\begin{array}{l}\text { Ftable } \\
5 \%\end{array}$ & $1 \%$ \\
\hline Treatments & 10 & 0.48653 & 0.04865 & 4.88742 & & \\
\hline$A=$ Quality & 2 & 0.00457 & 0.00229 & 0.22979 & 3.12 & 4.92 \\
\hline $\mathrm{B}=$ Diameter & 4 & 0.01343 & 0.00336 & 0.33719 & 2.35 & 3.29 \\
\hline C = RL Type & 1 & 0.00929 & 0.00929 & 0.93343 & 3.92 & 7.01 \\
\hline$A B$ & 8 & 0.01360 & 0.00170 & 0.17078 & 1.97 & 2.589 \\
\hline$A C$ & 2 & 0.00291 & 0.00145 & 0.14595 & 3.12 & 4.92 \\
\hline $\mathrm{BC}$ & 4 & 0.00770 & 0.00193 & 0.19345 & 2.35 & 3.29 \\
\hline$A B C$ & 8 & 0.43503 & 0.05438 & 5.46256 & 1.97 & 2.589 \\
\hline Error & 58 & 0.57738 & 0.00995 & & & \\
\hline Total & 89 & 1.06392 & & & & \\
\hline
\end{tabular}

Note: $n s=$ not significant different at $\alpha=0.05 ;{ }^{* *}=$ very significant different at $\alpha=0.01$; If the $F_{\text {count }}$ value $>F_{\text {table, }}$

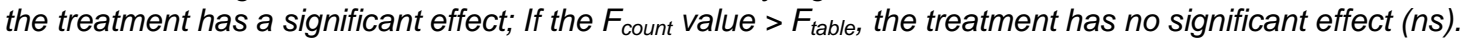

Table 6 - Analysis of Variance (ANOVA) Data of Log-Core Volumes in the $3 \times 2 \times 5$ Factorial Experimental Design

\begin{tabular}{|c|c|c|c|c|c|c|}
\hline \multirow{2}{*}{ Source } & \multirow{2}{*}{$\mathrm{db}$} & \multirow{2}{*}{ JK } & \multirow{2}{*}{$\mathrm{KT}$} & \multirow{2}{*}{ F-count } & \multicolumn{2}{|c|}{ F-table } \\
\hline & & & & & $5 \%$ & $1 \%$ \\
\hline Treatments & 10 & 0.10736 & 0.01074 & 4.8380 & & \\
\hline$A=$ Quality & 2 & 0.00104 & 0.00052 & $0.2341^{\mathrm{ns}}$ & 3.12 & 4.92 \\
\hline $\mathrm{B}=$ Diameter & 4 & 0.00215 & 0.00054 & $0.2419^{\text {ns }}$ & 2.35 & 3.29 \\
\hline C = RL Type & 1 & 0.00547 & 0.00547 & $2.4653^{\mathrm{ns}}$ & 3.92 & 7.01 \\
\hline$A B$ & 8 & 0.00312 & 0.00039 & $0.1755^{\mathrm{ns}}$ & 1.97 & 2.589 \\
\hline$A C$ & 2 & 0.00023 & 0.00012 & $0.0521^{\mathrm{ns}}$ & 3.12 & 4.92 \\
\hline$B C$ & 4 & 0.00109 & 0.00027 & $0.1223^{\mathrm{ns}}$ & 2.35 & 3.29 \\
\hline $\mathrm{ABC}$ & 8 & 0.09427 & 0.01178 & $5.3103^{\star *}$ & 1.97 & 2.589 \\
\hline Error & 58 & 0.12870 & 0.00222 & & & \\
\hline Total & 89 & 0.23606 & & & & \\
\hline
\end{tabular}

Note: $n s=$ not significant different at $\alpha=0.05 ;{ }^{* *}=$ very significant different at $\alpha=0.01$.

The results showed that both at the level of $1 \%$ and $5 \%$, the treatments had no significant effect on the volume of log-core or pith produced (Table 6). In theory, the log-core volume, indicated by the size of the diameter, will be influenced by the quality of raw material log-blocks, especially if the logs are healthy on the bontos, sufficiently cylindrical, and free from cracks (not broken), provided that the machine operator does not stop the peeling process for certain purposes.

The ANOVA table above also shows that the $F_{\text {count }}$ value of the difference in the types of rotary peeling lathes is quite close to the $F_{\text {table }}$ value at the level of 0.05 , indicating an almost significant effect on the volume of piths (log-block core) at the end of peeling. It was proven that the pith removed from the rotary clamps in the peeling machine had a diameter range of $20 \mathrm{~cm}$. Meanwhile, according to Philips, et al. (1980), the log-core diameter has a direct effect on the number of veneers produced. He found that the increase in veneers produced from 18-inch $(( \pm 50 \mathrm{~cm})$ sawn-logs reduced the log-core diameter from 5 to 4 inches (from $12.5 \mathrm{~cm}$ to $10 \mathrm{~cm}$ ), which was not significant (only about $3 \%$ ). In contrast, on the 8 -inch $(16.25 \mathrm{~cm}$ ) sawn-logs peeled, the difference became very significant (about $21 \%$ ).

Table 7 - Analysis of Variance (ANOVA) Data of Spur-Knife Waste Volumes in the $3 \times 2 \times 5$ Factorial Experimental Design

\begin{tabular}{|c|c|c|c|c|c|c|}
\hline Source & $\mathrm{db}$ & $\mathrm{JK}$ & KT & F-count & $\begin{array}{l}\text { F-table } \\
5 \%\end{array}$ & $1 \%$ \\
\hline Treatments & 9 & 0.56784 & 0.05678 & 2.9358 & & \\
\hline$A=$ Quality & 2 & 0.01314 & 0.00657 & $0.3396^{\text {ns }}$ & 3.12 & 4.92 \\
\hline $\mathrm{B}=$ Diameter & 4 & 0.01498 & 0.00375 & $0.1936^{\text {ns }}$ & 2.35 & 3.29 \\
\hline C = RL Type & 1 & 0.00162 & 0.00162 & $0.0837^{\mathrm{ns}}$ & 3.92 & 7.01 \\
\hline$A B$ & 8 & 0.04157 & 0.00520 & $0.2686^{\mathrm{ns}}$ & 1.97 & 2.589 \\
\hline$A C$ & 2 & 0.02163 & 0.01082 & $0.5592^{\text {ns }}$ & 3.12 & 4.92 \\
\hline $\mathrm{BC}$ & 4 & 0.02054 & 0.00514 & $0.2655^{\text {ns }}$ & 2.35 & 3.29 \\
\hline$A B C$ & 8 & -0.03727 & -0.00466 & $-0.2409^{\text {ns }}$ & 1.97 & 2.589 \\
\hline Error & 58 & 1.12184 & 0.01934 & & & \\
\hline Total & 89 & 1.76590 & & & & \\
\hline
\end{tabular}

Note: $n s=$ not significant different at $\alpha=0.05 ;{ }^{* *}=$ very significant different at $\alpha=0.01$. 
Table 7 suggests that from the analysis of variance (ANOVA) on the sources of variance in this study, it turned out that all forms of treatment did not have a significant effect on the volume of spur-knife waste. Instead, the volume of the spur-knife waste seemed to be more influenced by the allowance, the excess in the length of the log-blocks, which was sometimes too large, far from the desired veneer length.

\section{CONCLUSION}

The average yields of sawn-logs (log-blocks) peeled using the spindle-less rotary lathe reached $49.27 \%-58.66 \%$ of continuous/endless veneers; $18.20 \%-25.66 \%$ of poly piece core veneers; $11.84 \%-15.06 \%$ of piths or log-cores; $0.92-11.84 \%$ of cut-edge veneers (spur-knife waste). Meanwhile, the peeled yields using conventional rotary lathe showed $44.86 \%-61.48 \%$ of continuous veneers, $24.48 \%-26.72 \%$ of PPC veneers, $6.03 \%-0.95 \%$ of piths or log-cores, and $1.08 \%-3.26 \%$ cut-edge veneers (spur-knife waste). Based on the statistical tests with the factorial experimental design, it turns out that in general, individual factors such as the peeling machine types, the diameter and the quality of raw material logblocks do not have a significant effect on the yields of veneers or other materials produced in the block peeling process. However, the interaction of the three treatments tested showed a very significant effect on the yield of peeled veneers.

\section{REFERENCES}

1. Baldwin, R.F. (1981). Plywood Manufacturing Practices. Revised, Second Edition. Miller Freeman Publication, Inc. San Francisco.

2. Britannica. (2002). Encyclopedia Britannica 2002. Deluxe Edition. Dalam Bentuk CD Room.

3. Dumanauw, J.F. (1996). Mengenal Kayu. Pendidikan Industri Kayu Atas (PIKA). Penerbit Kanisius. Semarang.

4. Frûehwald, A. (1986). Plywood, A Short Introduction into Its Production, Quality Control and Properties. Visiting Professor to the Faculty of Forestry, Mulawarman University. Samarinda. (Not publicated).

5. Gaspersz, V. (1994). Metode Perancangan Percobaan untuk IImu-ilmu Pertanian, IImuilmu Teknik and Biologi. Armico. Bandung

6. Haygeen, J.G and Bowyer, J.L. (1993). Hasil Hutan and IImu Kayu, Suatu Pengantar. Terjemahan Hadikusumo, Sutjipto A. Gajahmada University press. Yogyakarta.

7. Kollmann, F.F.P. and Kuenzi, E.W. and Stamp, A.J. (1975). Principles of Wood Science and Technology. Wood Based-Material. Springer-Verlag. New York. Heidelberg Berlin.

8. Philips, D.R., Schoeder, J.G. and Clark, A. (1980). Reduce Pine Veneer Losses by Selecting Blocks Properly. For. Ind.

9. Schulte, A. and Schone, D. (1996). Dipterocarp Forest Ecosystems, Towards Sustainable Management. World Scientific. Singapore, New Jersey, London, Hongkong.

10. Steel, R.G.D. and Torrie, J.H. (1993). Prinsip and Prosedur Statistika, Suatu Pendekatan Biometrik. Edisi Kedua. Penerbit PT Gramedia. Jakarta.

11. Syafii, A. (2001). Analisis Volumetrik Konversi Kayu Bulat Menjadi Lembaran Finir pada Industri Kayulapis. Buletin Poltanesa. Volume I. No. 1. Politeknik Pertanian Negeri. Samarinda.

12. Syafii. (2019). Kayulapis, Teknik Pembuatan, Sifat-sifat and Kegunaannya. Penerbit Garis Putih Pratama. Makassar.

13. Wood, A.D. and Linn, T.G. (1950). Plywood, Their Development, Manufacture and Application. Revised Edition. W. \& A.K. Johnston, Limited. Edinburgh and London. 